ORIGINAL ARTICLE

\title{
Professional and medical outcomes for French train drivers after "person under train" accidents: three year follow up study
}

C Cothereau, C de Beaurepaire, C Payan, J P Cambou, F Rouillon, F Conso

Occup Environ Med 2004;61:488-494. doi: 10.1136/oem.2003.007922

Aims: To investigate psychiatric disorders, somatic health, and professional effects in French train drivers having experienced a "person under train" accident, and somatic health and professional effects.

Methods: A total of 202 train drivers were evaluated several times: immediately after the event, three months later, and one, two, and three years later. These drivers were compared with 186 train drivers not exposed to that psychotraumatic shock. The evaluations relied primarily on the GHQ-28 and MINI questionnaires.

Results: In the exposed group, at the first evaluation, the prevalence of post-traumatic stress was $4 \%$; scores $\geqslant 5$ on the GHQ- 28 were significantly higher than in the non-exposed group ( $32 \%$ versus $6 \%$ ), for

See end of article for authors' affiliations

Correspondence to:

Dr C Cothereau, SNCF, 44 rue de Rome, 75008 Paris,

France; catherine.

cothereau@sncf.fr

Accepted

28 November 2003 both the overall result and three sub-scores (somatic symptoms, anxiety and sleep, and psychosocial functioning). All these differences disappeared within a year. Vulnerability factors concerned prior traumas, acute and lasting life events, and the particular occupational situation where the driver is not accompanied but drives the train away alone in the aftermath of the accident. Over $95 \%$ of subjects had no short, medium, or long term impairment of their occupational fitness.

Conclusions: Most of the psycho-behavioural disorders were observed in the immediate aftermath of the accident and disappeared within a year. The driver's occupational future does not seem to be affected by the "person under train" accident. Consideration of a traumatic accident as a job related risk and close psychological support of drivers after an accident probably increase the subject's ability to recover from the event.
A "person under train" accident is defined on the French Railways as a violent impact, most often frontal, with a person who dies in most cases. On the French network, such an event occurs between 500 and 600 times a year. ${ }^{1}$ Experience shows that two out of three drivers will be confronted with such a situation in the course of their career; a very special situation because it is unpredictable, inevitable, and not related to a fault or to the driver's professional competence. Some pioneering studies were carried out in Denmark during the 1980s. ${ }^{2}$ Few studies however actually address our topic. Most of them include few drivers, and the only prospective studies ${ }^{3-5}$ encompass driver reactions only during the first year after the accident. Their objective was the immediate psychological impact, the prevalence of posttraumatic stress disorder (PTSD), and other psychiatric disorders such as depression and anxiety occurring within a maximum of one year. The long term outcome on the subject's professional life was not systematically studied. The prevalence of PTSD among drivers confronted with this traumatic psychological shock was greater than in the general population (17.1\% at one month). ${ }^{3}$ Studies in the general population indicate that the lifetime prevalence of PTSD is about $10 \%$, depending on many variables, especially the type of trauma. ${ }^{6-8}$ In light of these data*, the French Railways' medical department conducted its study over the years 1996 to 2000, following up drivers for three years after the accident, with the following objectives: to assess immediate effects, somatic health consequences, and prevalence of short and long term psychological effects (including

* Since our study, it was found that two months after the terrorist attacks of September 11, 2001, prevalence of PTSD was higher in New York (11.2\%) than elsewhere in the United States (4\%).
PTSD); to identify vulnerability factors; and to assess the professional outcome (work missed, permanent unfitness, and reclassification) and the effectiveness of the French Railways' preventive policy since 1995 of providing psychological support to drivers. ${ }^{10}$

\section{METHODS \\ Subjects}

The study was a prospective one in which the drivers confronted with a "person under train" accident constituted the exposed group. Each subject in this group was matched with a control. The study took place from 30 May 1996 to 30 September 2000. During the period of inclusion from May 1996 to September 1997, 437 male train drivers employed on the French railway network were recruited from 30 depots distributed throughout the territory, among the 56 major depots. These drivers are qualified to drive freight trains or passenger trains, the latter including mainlines (long distance) and regional trains. Every driver of the 30 depots who experienced a "person under train" accident during the period was recruited as a case. The only drivers excluded from the investigation were those who retired before the end of the survey. Thirty drivers refused to participate $(7 \%)$, and 19 drivers $(4 \%)$ were excluded from the analysis because the accident did not meet the criteria defined for a "person under train" accident. The study therefore included for analysis 388 drivers (202 exposed and 186 non-exposed). The control drivers were recruited on the basis of the following criteria:

Abbreviations: GAD, generalised anxiety disorder; GAF, Global Assessment of Functioning scale; GHQ, General Health Questionnaire; MINI, Mini International Neuropsychiatric Interview; OCD, obsessive compulsive disorder; PTSD, post-traumatic stress disorder 
Main messages

- The frequency of psychiatric disorders following a "person under train accident" is low among French train drivers.

- All of the disorders observed in the immediate aftermath of the accident disappeared in less than one year.

- Vulnerability factors are: prior trauma history, acute and sustained life events, and the professional situation where the driver is not accompanied and drives the train away alone immediately after the accident.

- The driver's occupational future does not seem to be affected by this event.

belonging to the same depot, being of the same age \pm 5 years, having the same level of professional qualification and driving the same types of train (mainlines, goods, regional trains), and having no prior history of a person under train accident on the date of inclusion into the control (nonexposed) group. The next driver showing up for his regular occupational health appointment after the inclusion of a driver confronted with a "person under train" accident and fulfilling the above defined criteria was selected for inclusion in the non-exposed group.

\section{Study design}

Each driver confronted with a "person under train" accident was evaluated immediately after the accident and again three months, and one, two, and three years after the accident. Only one assessment was made of the non-exposed group.

The assessment used different instruments to evaluate the following conditions: psychiatric disorders, somatic health, occupational fitness, and vulnerability factors.

\section{Psychiatric disorders}

Psychiatric disorders were explored with the 28 item General Health Questionnaire (GHQ-28) ${ }^{11}$ and the Mini International Neuropsychiatric Interview (MINI), version $4.4 .^{13}$ The GHQ is a screening instrument for psychiatric disorders throughout the general population. Different forms (60 item, 30 item, 28 item, and 12 item) are internationally validated. The 28 item version has a sensitivity of about $72 \%$ and a specificity of about $74 \%$, which are both good criteria of validity. ${ }^{12}$ The GHQ-28 explores four categories of psychiatric disorder: somatic symptoms, anxiety and insomnia, social dysfunction, and depression (seven items each). It is a self questionnaire completed by the subjects, asking them to qualify their condition over the preceding weeks compared with their usual condition. It was given by the occupational physicians involved in the study. Each item is analysed to yield a bimodal response giving the value 0 for responses "less than usual" or "not more than usual" and 1 for "a little more" or "much more than usual". The overall score obtained represents a severity index. A threshold GHQ score of 5 and more can be considered as an indicator of psychiatric disorders. ${ }^{14}$ Each of the four areas explored by the GHQ-28 was analysed by summing the corresponding items ranked on a four point scale (from 0 to 3 ) to calculate the mean of the scores obtained.

In our study, the MINI interview was administered by the occupational physician only, previously trained in the utilisation of this standardised instrument. MINI is a brief structured diagnostic interview (15 minutes) exploring each of the criteria corresponding to the diagnosis of Axis I of DSM IV: ${ }^{15}$ major depression, dysthymia, mania, agoraphobia, panic
Policy implications

- A closer medical follow up during the first year is essential in a preventive approach.

- Professional support, and professional and medical accompaniment are essential.

disorder, social phobia, generalised anxiety disorder (GAD), obsessive compulsive disorder (OCD), PTSD, mental anorexia, bulimia, alcoholism, or psychotic and somatic symptoms. The sensitivity varies with the diagnosis, from $62 \%$ (OCD) to $96 \%$ (depression), and the specificity is more than $85 \% .^{13}$

\section{Somatic health}

A complete clinical examination established the driver's somatic state. No further examination was required.

\section{Occupational fitness}

Occupational fitness is evaluated by an unspecified protocol, by the occupational physician. It is graduated into four categories: "fit" (the driver is then checked again a year later), "fit but requiring medical review in less than one year", "temporarily unfit", and "permanently unfit". A driver deemed permanently unfit must be transferred to another type of job (reclassification). A medical interview was used to collect occupational events (absenteeism, occupational fitness on the day of the regular annual medical appointment).

\section{Vulnerability factors}

Two scales were used to assess the psychological, social, and professional functioning according to DSM III-R criteria: ${ }^{16}$ the first assessed the severity of the psychosocial stressors, acute events, and lasting circumstances (axis IV of DSM III-R) with a score of 1-6 (6 being the highest stress intensity level); the second assessed the current psychosocial functioning (axis V of DSM III-R) using the Global Assessment of Functioning scale (GAF) with a score of $1-90$ (satisfactory social functioning in all areas is given the mark 90). The medical interview used a questionnaire filled in by the occupational physician with the driver to collect the sociodemographic characteristics and antecedents.

\section{Statistical analysis}

Comparisons of categorical data such as medical, sociodemographic, occupational characteristics, and psychiatric disorders between the study subgroups (exposed versus nonexposed) were assessed by the $\chi^{2}$ test or Fisher's exact probability test. Comparisons of continuous parameters were made using Student's $t$ test (age, GHQ sub-scores) or the Mann-Whitney non-parametric test (number of children, number of days of sick leave). Within the exposed group, vulnerability factors were compared using similar tests. A p value at the $5 \%$ level was considered significant. The database relies on Paradox software and the statistical analyses were performed using BMDP software.

\section{RESULTS}

For the follow up of the exposed group, $83 \%$ of the cohort (168 drivers) were assessed at least once, two or three years after the accident. The drivers not seen again at the last assessment had either been transferred to another region $(9 \%)$, refused to continue with the study $(7 \%)$, retired $(5 \%)$, failed to be called to the medical examination $(2 \%)$, were on 
sick leave $(1 \%)$, or were assessed outside the stipulated timeframe $(1 \%)$.

\section{Characteristics of the accident experienced by the exposed group}

The accident occurred on open track in more than half the cases. It generally arose in the course of driving regional trains or suburban trains. The victim was usually alone; rarely were one or two other persons involved (three cases in our study). Generally, the victim was an adult male $(66.3 \%$ versus female $30.1 \%$, child $2.4 \%$, or elderly $12.7 \%$ ). Suicide was the major cause and the victim died in $80 \%$ of the cases. In most cases, the driver saw the person before the accident and the body afterwards. Table 1 sets out the characteristics of the accident for the exposed group.

\section{Medical and socio-professional characteristics of the exposed and non-exposed}

No significant difference was found between the exposed and non-exposed groups in respect of the frequency of medical, surgical, or traumatic experiences and of personal psychobehavioural and family psychiatric history (table 2 ).

\section{Psycho-behavioural disorders at the first assessment}

Post-traumatic stress related symptoms were more frequent in the exposed group than in the non-exposed group (4\% versus $0 \%, p=0.0001$ ) (table 3 ). A statistically significant difference was found for the total score on the GHQ-28 (GHQ-28 score $\geqslant 5: 32 \%$ versus $6 \%, p=0.0001$ ) with higher sub-scores on somatic symptoms, anxiety/insomnia, and social dysfunction in the exposed group. The latter also had a lower psychosocial functioning score (score $<80$ : $7 \%$ versus $1 \%, p=0.01)$. Conversely, the results of the semi-structured interview (MINI) revealed no significant difference if the selected criterion was the existence of at least one psychiatric disorder ( $11 \%$ of the drivers in the exposed group and $9 \%$ of those in the non-exposed group).

\section{Evolution of psycho-behavioural disorders}

Table 4 presents the evolution of psycho-behavioural disorders. The symptoms of post-traumatic stress gradually

Table 1 Characteristics of the accident for the exposed group $(n=202)$

\begin{tabular}{lc}
\hline Location & \\
Track & $55 \%$ \\
Yard & $29 \%$ \\
Level crossing & $16 \%$ \\
Type of train & \\
$\quad$ Shunting & $2 \%$ \\
Goods & $18 \%$ \\
Regional & $40 \%$ \\
Mainlines & $29 \%$ \\
TGV (HST) & $11 \%$ \\
Type of accident & \\
Suicide & $59 \%$ \\
Accident & $27 \%$ \\
Undetermined & $14 \%$ \\
Sex of victim & \\
Male & $66.3 \%$ \\
Female & $30.1 \%$ \\
Unknown & $3.6 \%$ \\
Age of victim & \\
$\quad<18$ years & $2.4 \%$ \\
18-65 years & $64.5 \%$ \\
$\quad$ > 65 years & $12.7 \%$ \\
Unknown & $20.4 \%$ \\
Driver distinguished victim before accident & $79 \%$ \\
Driver saw body after accident & $75 \%$ \\
At least one death per accident & $80 \%$ \\
At least one injured per accident & $20 \%$ \\
\hline & \\
\hline
\end{tabular}

Table 2 Medical, socio-demographic, and occupational characteristics of the exposed and non-exposed groups

\begin{tabular}{|c|c|c|c|}
\hline & $\begin{array}{l}\text { Non-exposed } \\
\text { group } \\
(n=186)\end{array}$ & $\begin{array}{l}\text { Exposed } \\
\text { group } \\
(n=202)\end{array}$ & $\mathbf{p}$ \\
\hline Average age (years) & $39 \pm 6.3$ & $39.1 \pm 6.5$ & NS \\
\hline Age range & $21-51$ y & $21-53 y$ & \\
\hline \multicolumn{4}{|l|}{ Family status } \\
\hline Single & $10 \%$ & $12 \%$ & NS \\
\hline Couple & $87 \%$ & $84 \%$ & \\
\hline Separated & $3 \%$ & $4 \%$ & \\
\hline Number of children & $1.8 \pm 1.1$ & $1.6 \pm 1.1$ & \\
\hline Children $<18$ & $1.7 \pm 1.0$ & $1.5 \pm 0.9$ & \\
\hline \multicolumn{4}{|l|}{ History events } \\
\hline Medical & $9 \%$ & $8 \%$ & NS \\
\hline Surgical & $31 \%$ & $23 \%$ & NS \\
\hline Psychiatric & $2 \%$ & $3 \%$ & NS \\
\hline Traumatic & $46 \%$ & $38 \%$ & NS \\
\hline (average total number) & $(2.3 \pm 2.5)$ & $(2.4 \pm 2.3)$ & NS \\
\hline Person-train accident & 0 & $34 \%$ & $S p<10^{-4}$ \\
\hline \multicolumn{4}{|c|}{ Psychiatric history in family } \\
\hline Father & $2 \%$ & $2 \%$ & NS \\
\hline Mother & $2 \%$ & $3 \%$ & NS \\
\hline Sibling & $2 \%$ & $3 \%$ & NS \\
\hline $\begin{array}{l}\text { Abnormal somatic } \\
\text { examination }\end{array}$ & $7.5 \%$ & $5.5 \%$ & NS \\
\hline
\end{tabular}

decreased over the successive assessments and were absent by the time of the third year assessment. The later appearance, two and three years after the accident, of generalised anxiety symptoms is associated with the occurrence of acute life events (death of father in both cases). The frequency of disorders after three years was still less than

Table 3 Psycho-behavioural disorders in the two groups at first assessment

\begin{tabular}{|c|c|c|c|}
\hline & $\begin{array}{l}\text { Non- } \\
\text { exposed } \\
(n=186)\end{array}$ & $\begin{array}{l}\text { Exposed } \\
\left(\mathrm{n}=198^{*}\right)\end{array}$ & $\mathbf{p}$ \\
\hline \multicolumn{4}{|l|}{ MINI version 4.4 DSM IV } \\
\hline At least one diagnosis & $9.1 \%$ & $10.9 \%$ & NS \\
\hline Severe depression & $0.5 \%$ & $1.5 \%$ & NS \\
\hline Dysthymia & $0.5 \%$ & $1 \%$ & NS \\
\hline Manic episode & $0.5 \%$ & $0.5 \%$ & NS \\
\hline Panic disorder & $0 \%$ & $0.5 \%$ & NS \\
\hline Agoraphobia & $2.7 \%$ & $2.5 \%$ & NS \\
\hline Social phobia & $0 \%$ & $1.5 \%$ & NS \\
\hline OCD & $0 \%$ & $0 \%$ & NS \\
\hline Generalised anxiety & $1 \%$ & $4 \%$ & NS \\
\hline Alcoholism & $3.8 \%$ & $1.5 \%$ & NS \\
\hline Psychosis & $0 \%$ & $0 \%$ & NS \\
\hline Anorexia & $0 \%$ & $0 \%$ & NS \\
\hline Bulimia & $0 \%$ & $0 \%$ & NS \\
\hline PTSD & $0 \%$ & $4 \%$ & $p<10^{-4}$ \\
\hline Somatic symptoms & $0.5 \%$ & $0.5 \%$ & NS \\
\hline \multicolumn{4}{|l|}{ GHQ-28 } \\
\hline Score $\geqslant 5$ & $6 \%$ & $32 \%$ & $S p<10^{-4}$ \\
\hline \multicolumn{4}{|l|}{ Sub-score (mean) } \\
\hline Somatic symptoms & $2.6 \pm 2.4$ & $4.3 \pm 3.4$ & $S p<10^{-4}$ \\
\hline Anxiety/insomnia & $3.1 \pm 2.5$ & $4.9 \pm 4.2$ & $S p<10^{-4}$ \\
\hline Social dysfunction & $6.9 \pm 0.7$ & $7.3 \pm 1.6$ & $S p<10^{-3}$ \\
\hline Depression & $0.8 \pm 1.6$ & $0.9 \pm 1.8$ & NS \\
\hline \multicolumn{4}{|l|}{ Stress factors $(\geqslant 2)$} \\
\hline Acute & $15 \%$ & $15 \%$ & NS \\
\hline Sustained & $11 \%$ & $14 \%$ & NS \\
\hline $\begin{array}{l}\text { Current psychosocial functioning } \\
(<80)\end{array}$ & $1 \%$ & $7 \%$ & $S p=0.01$ \\
\hline Psychotropic treatments & $0 \%$ & $6 \%$ & $S p=0.007$ \\
\hline Tranquilliser & & $2.5 \%$ & \\
\hline Hypnotic & & $3 \%$ & \\
\hline Antidepressant & & $1 \%$ & \\
\hline Neuroleptic & & $0 \%$ & \\
\hline Other & & $0.5 \%$ & \\
\hline
\end{tabular}


what had been observed in the first assessment. A GHQ-28 score $\geqslant 5$ was found in the first assessment for one third of the drivers $(32 \%)$. After three months, only $5.5 \%$ of the drivers were concerned. That percentage remained stable thereafter. At the three year assessment, it was less (3.7\%) than the rate found in the non-exposed group (6\%). A similar evolution was observed for the somatic and anxiety/ insomnia sub-scores. The frequency of subjects with a psychosocial functioning score of less than 80 decreased over time, and after three years only $1.3 \%$ of the followed up drivers were concerned (a frequency comparable to that observed in the non-exposed population). Acute and sustained stress factors were found in $15 \%$ and $14 \%$ of exposed drivers, respectively. The variations observed over time were similar to those already mentioned with regard to the symptoms of generalised anxiety (over the two year and three year timeframes). Furthermore, the prescription of psychotropic treatments dropped after the first assessment until it fell practically to the level of prescription for the non-exposed group. Few drivers received psychotherapeutic support $(2.2 \%$ at three months and $1.3 \%$ at three years).

\section{New events}

The rate of medical events over the three years was $7 \%$, that of surgical events $2.7 \%$, and psychiatric events $0.8 \%$. None of these events can be directly related to the "person under train" accident.

\section{Vulnerability factors}

For the group of exposed subjects, we compared the symptomatic subjects ("cases") with the non-symptomatic subjects (table 5 ), the cases being defined by a GHQ- $28 \geqslant 5$, and/or a psychosocial functioning $<80$, and/or the presence of at least one disorder on the MINI. These two subgroups of the exposed group were found to differ by the following characteristics: presence of traumatic events, presence of an acute stress factor, existence of a sustained stress, and lack of accompaniment of the driver following the accident (driver drove the train away alone in the aftermath). The prescription of a psychotropic treatment and the number of days of leave appear in all logic to be a function of the subject's psychological state.

\section{Occupational events \\ Sick leave}

Nearly $70 \%$ of the drivers were given temporary sick leave after the "person under train" accident. The average time of that leave (4.4 days) was short. Since 1994, "person under train" accidents have been included by French legislation in the "occupational accident" category. In fact a job related accident was declared in 99\% of the cases. Table 6 summarises the change in the number of drivers having been granted sick leave and the average number of days of sick leave taken by the drivers in the exposed group over the period studied. In the period 1-3 months following the "person under train" accident, 24 drivers (12.4\%) took sick

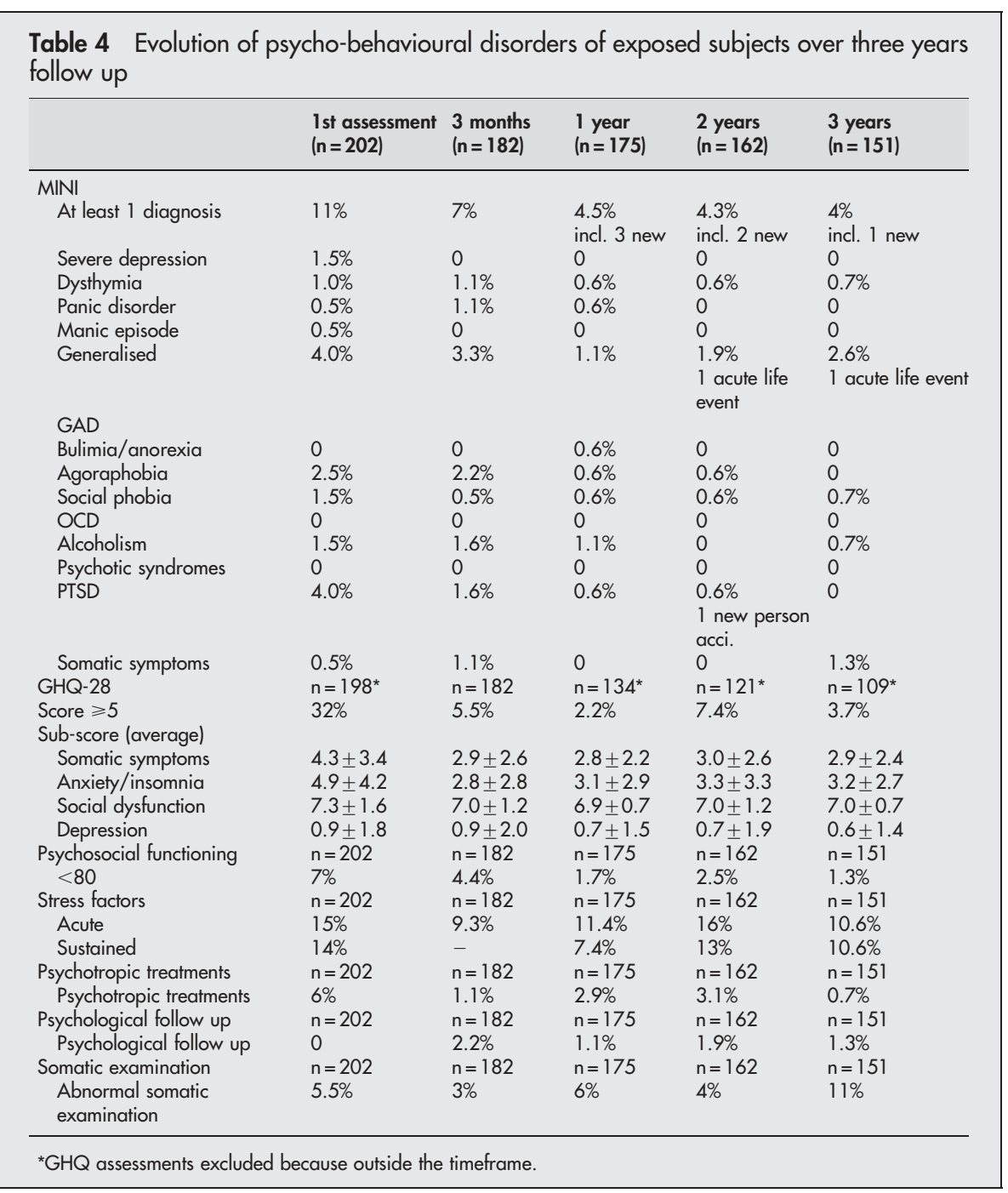


Table 5 Vulnerability factors for the exposed group

\begin{tabular}{|c|c|c|c|}
\hline & $\begin{array}{l}\text { Symptomatic } \\
\text { subjects } \\
(\mathrm{n}=76)\end{array}$ & $\begin{array}{l}\text { Non- } \\
\text { symptomatic } \\
\text { subjects } \\
(n=124)\end{array}$ & $\mathbf{p}$ \\
\hline $\begin{array}{l}\text { Age } \\
\text { Family situation (married) } \\
\text { Number of children }\end{array}$ & $\begin{array}{l}39 \pm 7 \\
86 \% \\
1.7 \pm 1.1\end{array}$ & $\begin{array}{l}39 \pm 6 \\
83 \% \\
1.5 \pm 1.1\end{array}$ & $\begin{array}{l}\text { NS } \\
\text { NS } \\
\text { NS }\end{array}$ \\
\hline $\begin{array}{l}\text { Medical history } \\
\text { Surgical history } \\
\text { Psychiatric history } \\
\text { Traumatic events } \\
\text { Person-train accident } \\
\text { Family psychol. history }\end{array}$ & \begin{tabular}{l|l}
$9 \%$ \\
$26 \%$ \\
$5 \%$ \\
$47 \%$ \\
$43 \%$ \\
$11 \%$ \\
\end{tabular} & $\begin{array}{l}7 \% \\
22 \% \\
2 \% \\
32 \% \\
52 \% \\
6 \%\end{array}$ & $\begin{array}{l}\text { NS } \\
\text { NS } \\
\text { NS } \\
p<0.05 \\
\text { NS } \\
\text { NS }\end{array}$ \\
\hline $\begin{array}{l}\text { Acute stress factors } \\
\text { Sustained stress situation }\end{array}$ & $\begin{array}{l}24 \% \\
26 \%\end{array}$ & $\begin{array}{l}11 \% \\
7 \%\end{array}$ & $\begin{array}{l}p<0.05 \\
p<0.001\end{array}$ \\
\hline Abnormal somatic exam & $9 \%$ & $3 \%$ & NS \\
\hline $\begin{array}{l}\text { Psychiatric follow up } \\
\text { Psychotropic treatment } \\
\text { immediately }\end{array}$ & $\begin{array}{l}8 \% \\
13 \%\end{array}$ & $\begin{array}{l}7 \% \\
2 \%\end{array}$ & $\begin{array}{l}\text { NS } \\
p<0.001\end{array}$ \\
\hline $\begin{array}{l}\text { Psychotropic treatment } \\
\text { during the study }\end{array}$ & $34 \%$ & $17 \%$ & $\mathrm{p}<0.01$ \\
\hline Accident: suicide & $64 \%$ & $56 \%$ & NS \\
\hline Immediate help & $67 \%$ & $74 \%$ & NS \\
\hline De-rostered & $43 \%$ & $41 \%$ & \\
\hline Drove away alone & $12 \%$ & $3 \%$ & $p<0.05$ \\
\hline Drove away accompanied & $45 \%$ & $56 \%$ & \\
\hline $\begin{array}{l}\text { Declared as occupational } \\
\text { accident }\end{array}$ & $99 \%$ & $99 \%$ & NS \\
\hline Number of days of leave & $5.4 \pm 3.2$ & $3.7 \pm 1.6$ & $p<0.001$ \\
\hline
\end{tabular}

leave with an average duration of 15 days. From three months to one year after the accident, 49 drivers (28\%) had sick leaves of 16 days on average. In the period up to two years, 56 drivers (35\%) had taken sick leave of 13 days on average. At three years, 53 drivers took an average of 17 days' leave. Six of the eight drivers meeting the PTSD criteria took sick leaves for a length of time comparable to that of the other drivers in the exposed group.

\section{Occupational fitness of the exposed group evaluated at each assessment}

In $95-97.5 \%$ of cases, the train driver's medical fitness for the job was confirmed in the successive assessments (table 7). In this study, only one driver was found unfit to drive, in the last assessment, and was transferred to a non-driving job. That driver had presented a post-traumatic stress syndrome at the first assessment. The three month and one year assessments had been normal but the driver refused subsequent assessments: it was not possible to relate in this medical decision with the "person under train" accident. A temporary unfitness was declared for three drivers (respectively for a serious knee sprain, deafness, and depression linked to a non-job related legal problem). In $1-4.5 \%$ of the cases, the fitness assessment was given together with a
Table 7 Occupational fitness at each assessment of the exposed group

\begin{tabular}{|c|c|c|c|c|}
\hline & $\begin{array}{l}3 \text { months } \\
(n=182)\end{array}$ & $\begin{array}{l}1 \text { year } \\
(n=175)\end{array}$ & $\begin{array}{l}2 \text { years } \\
(n=162)\end{array}$ & $\begin{array}{l}3 \text { years } \\
(n=151)\end{array}$ \\
\hline Fit until annual visit & $95 \%$ & $95 \%$ & $97.5 \%$ & $95 \%$ \\
\hline $\begin{array}{l}\text { Fit but review before } \\
1 \text { year }\end{array}$ & $4.5 \%$ & $4 \%$ & $2.5 \%$ & $1 \%$ \\
\hline Temporarily unfit & $0.5 \%$ & 0 & 0 & $1 \%$ \\
\hline $\begin{array}{l}\text { Permanently unfit and } \\
\text { reclassified }\end{array}$ & 0 & 0 & 0 & $0.6 \%$ \\
\hline No data & $0.5 \%$ & $0.6 \%$ & 0 & 0 \\
\hline Retired & 0 & 0 & 0 & $1 \%$ \\
\hline
\end{tabular}

recommendation for a medical visit in less than one year for various reasons (hypercholesterolaemia, arterial hypertension, knee sprain, anxiety about being sued, other "person under train" accident, ongoing medical examination). All these decisions were taken outside the context of the "person under train" accident.

\section{Experience of another "person under train"} accident during the period of the study

Of the exposed group, 29 drivers (15\%) were confronted with another "person under train" accident, three of the 29 with two new accidents and one with three new accidents.

\section{DISCUSSION}

Concerning the immediate effects, our study shows a prevalence of subjects with a GHQ-28 score $\geqslant 5$, significantly higher in the exposed group than in the non-exposed population ( $32 \%$ versus $6 \%$ ), both concerning the total result and three sub-scores (somatic symptoms, anxiety/insomnia, social dysfunction). Tranah and Farmer ${ }^{3}$ showed that 10 subjects out of 13 had GHQ-28 scores of $\geqslant 5$ and $6 \%$ of the subjects were rated as cases by the GHQ-20 in Karlehagen and colleagues' study. ${ }^{4}$ Vatschelle and Moen $^{17}$ found no significant difference between the drivers involved in accidents and controls concerning alcoholic behaviour, sleep disorders, depression, and phobias. The prospective study by Theorell et al, ${ }^{18}$ based on a population of 98 drivers of the Swedish subway followed up for one year shows that sleep disorders assessed three weeks after the accident were significantly more frequent in the exposed group than in the control group. Conversely, no difference was found concerning depression, anxiety, and phobia.

The prevalence of the post-traumatic stress diagnosis at the first assessment was $4 \%$ in the exposed group. This figure is smaller than the prevalence reported in most other studies, ${ }^{3} 19$ but is closer to the prevalence found where the assessments were administered by occupational physicians ${ }^{40}$ rather than psychiatrists, and where the drivers received particular aftercare attention. ${ }^{4}$ Drivers can minimise their own immediate reactions to keep their driving licence. Most studies agree that drivers quickly return to normal. Tranah and Farmer for example, ${ }^{319}$ also showed that after six months not a single driver suffered from post-traumatic stress. In our study, the

Table 6 Sick leave

\begin{tabular}{|c|c|c|c|c|c|}
\hline & $\begin{array}{l}\text { 1st assessment } \\
(n=202)\end{array}$ & $\begin{array}{l}3 \text { months } \\
(n=193)\end{array}$ & $\begin{array}{l}1 \text { year } \\
(n=176)\end{array}$ & $\begin{array}{l}2 \text { years } \\
(n=162)\end{array}$ & $\begin{array}{l}3 \text { years } \\
(n=151)\end{array}$ \\
\hline $\begin{array}{l}\text { Number of drivers given sick leave } \\
\text { Average number of days of sick leave } \\
\text { Range }\end{array}$ & $\begin{array}{l}139(69 \%) \\
4.4 \pm 2.5 \\
2-17 \text { days }\end{array}$ & $\begin{array}{l}24(12 \%) \\
15.1 \pm 17.8 \\
1-74 \text { days }\end{array}$ & $\begin{array}{l}49(28 \%) \\
15.7 \pm 18.8 \\
1-81 \text { days }\end{array}$ & $\begin{array}{l}56(35 \%) \\
13.1 \pm 20.8 \\
2-120 \text { days }\end{array}$ & $\begin{array}{l}53(35 \%) \\
17.2 \pm 31.6 \\
1-150 \text { days }\end{array}$ \\
\hline
\end{tabular}


evolution of the initial distresses identified by the MINI and the GHQ was good since the subjects returned to normal within one year.

Our study shows that vulnerability factors could be traumatic events, acute stress factors, sustained stress, and lack of accompaniment of the driver after the accident. Regarding vulnerability, most of the authors have found that accidents causing death or serious injury to other persons are as traumatic for the driver as collisions between trains where the driver's own life is directly threatened. ${ }^{5}{ }^{57}$ It is well known that the subjective significance to and interpretation of the event by the driver condition his own reactions. ${ }^{4}$

The driver's occupational future does not seem to be affected by the "person under train" accident. In our study, in more than $95 \%$ of cases, no negative short, medium, or long term impact on occupational fitness was found. No study reports any occupational reclassification or conversion among the populations studied. However, the duration of follow up is probably too short to evaluate such career events. In our study, the proportion of drivers having gone on sick leave is high: $12-35 \%$ of the exposed drivers had taken sick leave several times during the study. The authors ${ }^{518}$ who have taken an interest in absenteeism for sickness among train drivers confronted with a "person under train" accident as compared with a control population have shown that the number and duration of sick leaves were significantly higher in the exposed group during the first three weeks following the accident. Other authors ${ }^{319}$ show that the frequency and duration of sick leaves appear to bear a relation with the intensity and type of reactions observed in the aftermath of the accident. In the Karlehagen et al study, ${ }^{4}$ less than $10 \%$ of the drivers took more than one week's leave. These figures are much lower than those reported in the other studies. The difference may possibly be explained by the type of support given the subject and particularly the follow up given by the occupational medicine staff. The medical support consists of a close follow up in the first year, with a first medical appointment as soon as possible after the accident, then regularly at the request of the driver. The medical examination helps the driver to express his feelings to the physician. The job related context of the "person under train" accident and the social and professional support seem to improve significantly the driver's psychological condition. Our study shows a favourable evolution of the symptoms, which contributes to drivers keeping their job. The low prevalence rate of psychiatric disorders in our study may be explained by the strong support given by the occupational group and the recognition of the "person under train" accident as an occupational accident.

\section{CONCLUSION}

The frequency of psycho-behavioural disorders following a "person under train" accident is low among the population of French train drivers. Compared with the non-exposed group, the exposed group had however a higher frequency of symptoms corresponding to a post-traumatic stress disorder and more often had a GHQ-28 score of $\geqslant 5$, more particularly on the social dysfunction, anxiety/insomnia, and somatic symptoms. Most of the disorders were observed in the immediate aftermath of the accident. All disappeared quickly, in less than one year.

The study of the vulnerability factors among the subjects diagnosed with psycho-behavioural disorders in the first assessment (34\% of the drivers in the exposed group) shows that there is a correlation with a number of characteristics specific to the accident and the driver, which may constitute vulnerability inducing factors. These factors are: prior trauma history, acute and sustained life events, and a quite specific occupational situation-that where the driver is not accompanied and drives the train away alone in the aftermath of the accident. The latter point supports the decisions taken by the railway to generalise the procedure of relieving the driver confronted with the "person under train" accident. This study highlights the drivers' outstanding capability to confront the situation from the start and to recover with no manifest disorder after a time. However, it appears important to carefully survey such employees for lasting, acute stress factors which are one of the factors contributing to an unfavourable subsequent evolution. The policy followed today by the French Railways in the domain of job related psychological traumas takes account of this evolutionary factor in its post-trauma support measures. ${ }^{10}$ If the "person under train" accident could be recognised as a specific risk regarding this kind of job, then the situation could be experienced by drivers as an occupational risk. In a preventive approach, a better knowledge of the vulnerability factors and an evaluation of the driver support and accompaniment schemes are essential.

\section{ACKNOWLEDGEMENTS}

We thank the following occupational physicians for taking part in the study: Drs JC Archange, A Ausset, P Barbaret, B Bestue, T Billioud, E Blanchard-Mohn, G Bronner, JP Cambou, P Carmouze, M Chahbendérian, C Cothereau, G Coulombier, A Cuffit, C d'Estève de Pradel, J Donnet, JC Eichenholc, C Empereur, P Guigner, H Guillemin, E Guillon, M Horard, E Keil, A Lebigot, V Le Rest, A Menoux-Ducrocq, B Michaud, P Millet, A Napolier, R Oberthur, A Richardot, MP Severyns, S Simon, PM Thérond, C Thomas, D Timsit, C Tirel, and C Vayre.

\section{Authors' affiliations}

C Cothereau, C de Beaurepaire, J P Cambou, F Conso, Société

Nationale des Chemins de Fer Français (SNCF), Direction des

Ressources Humaines, Département des Services Médicaux, Paris,

France

C Payan, Hôpital La Pitié-Salpêtrière, 43-87 Bd de l'Hopital, 75013

Paris, France

F Rouillon, Hôpital Chenevier, 40 rue de Mesly, 94000 Créteil, France

\section{REFERENCES}

1 SNCF. SNCF statistique générale des accidents et incidents des chemins de fer: récapitulatif annuel: 1986-1999. Paris, France: SNCF, 1999.

2 Beckmann J. Railway accidents and suicides. The engine driver's situation. Odense: IDEAS, 1989

3 Tranah T, Farmer RD. Psychological reactions of drivers to railway suicide. Soc Sci Med 1994;38:459-69.

4 Karlehagen S, Malt UF, Hoff H, et al. The effect of major railway accidents on the psychological health of train drivers - II. A longitudinal study of the oneyear outcome after the accident. J Psychosom Res 1993;37:807-17.

5 Theorell $\mathrm{T}$, Leymann $\mathrm{H}$, Jodko $M$, et al. "Person under train" incidents from the subway driver's point of view. A prospective 1-year follow up study: the design, and medical and psychiatric data. Soc Sci Med 1994;38:471-5.

6 Breslau N, Glenn CD. Posttraumatic stress disorder in an urban population of young adults: risk factors for chronicity. Am J Psychiatry 1992;149:671-5.

7 Malt U. The long-term psychiatric consequences of accidental injury. A longitudinal study of 107 adults. Br J Psychiatry 1988;153:810-18

8 Kessler RC, Sonnega A, Bromet E, et al. Posttraumatic stress disorder in the National Comorbidity Survey. Arch Gen Psychiatry 1995;52:1048-60.

9 Schlenger WE, Cadell JM, Ebert $L$, et al. Psychological reactions to terrorist attacks. Findings from the national study of Americans' reactions to September 11. JAMA 2002;288:581-8.

10 Beaurepaire de C, Cothereau C, Horard-Gidoudeau M, et al. Troubles psycho-traumatiques sur les réseaux ferroviaires: place du médecin du travail. Arch Mal Prof 1999;60:748-54.

11 Golberg D. GHQ-28: a scale version of health questionnaire. Psychol Med 1979;9:139-45.

12 Pariente $\mathbf{P}$, Challiat $\mathrm{H}$, Mesbah $M$, et al. The GHQ-28 questionnaire in French: a validation survey in a panel of 158 general psychiatric patients. Eur Psychiatry 1992;7:15-20.

13 Lecrubier Y, Sheehan DV, Weiller E, et al. The Mini-International Neuropsychiatric Interview (MINI). A short diagnostic structured interview: reliability and validity according to the CIDI. Eur Psychiatry 1997;12:224-31.

14 Goldberg DP, Williams P. A user's guide to the General Health Questionnaire. NFER-Nelson, 1998. 
15 American Psychiatric Association. Diagnostic and Statistical Manual of Mental Disorders (DSM IV). Washington: American Psychiatric Association Press, 1994

16 American Psychiatric Association. Diagnostic and Statistical Manual of Mental Disorders. Third edition, revised (DSM III-R). Washington: American Psychiatric Association Press, 1987.

17 Vatshelle A, Moen BE. Serious on-the-track accidents experienced by train drivers: psychological reactions and long-term health effects. J Psychosom Res 1997;42:43-52.
18 Theorell $\mathrm{T}$, Leymann $\mathrm{H}$, Jodko $M$, et al. "Person under train" incidents: medical consequences for subway drivers. Psychosom Med 1992;54:480-8.

19 Farmer R, Tranah T, O'Donnell I, et al. Railway suicide: the psychological effects on drivers. Psychol Med 1992:22:407-14.

20 Malt UF, Karlehagen S, Hoff H, et al. The effect of major railway accidents on the psychological health of train drivers. Acute psychological responses to accidents. J Psychosom Res 1993;37:793-805.

\section{Clinical Evidence - Call for contributors}

Clinical Evidence is a regularly updated evidence based journal available worldwide both as a paper version and on the internet. Clinical Evidence needs to recruit a number of new contributors. Contributors are health care professionals or epidemiologists with experience in evidence based medicine and the ability to write in a concise and structured way.

\section{Currently, we are interested in finding contributors with an interest in the following clinical areas:}

Altitude sickness; Autism; Basal cell carcinoma; Breast feeding; Carbon monoxide poisoning; Cervical cancer; Cystic fibrosis; Ectopic pregnancy; Grief/bereavement; Halitosis; Hodgkins disease; Infectious mononucleosis (glandular fever); Kidney stones; Malignant melanoma (metastatic); Mesothelioma; Myeloma; Ovarian cyst; Pancreatitis (acute); Pancreatitis (chronic); Polymyalgia rheumatica; Post-partum haemorrhage; Pulmonary embolism; Recurrent miscarriage; Repetitive strain injury; Scoliosis; Seasonal affective disorder; Squint; Systemic lupus erythematosus; Testicular cancer; Varicocele; Viral meningitis; Vitiligo However, we are always looking for others, so do not let this list discourage you.

\section{Being a contributor involves:}

- Appraising the results of literature searches (performed by our Information Specialists) to identify high quality evidence for inclusion in the journal.

- Writing to a highly structured template (about 2000-3000 words), using evidence from selected studies, within 6-8 weeks of receiving the literature search results.

- Working with Clinical Evidence Editors to ensure that the text meets rigorous epidemiological and style standards.

- Updating the text every eight months to incorporate new evidence.

- Expanding the topic to include new questions once every 12-18 months.

If you would like to become a contributor for Clinical Evidence or require more information about what this involves please send your contact details and a copy of your CV, clearly stating the clinical area you are interested in, to Claire Folkes (cfolkes@bmigroup.com).

\section{Call for peer reviewers}

Clinical Evidence also needs to recruit a number of new peer reviewers specifically with an interest in the clinical areas stated above, and also others related to general practice. Peer reviewers are health care professionals or epidemiologists with experience in evidence based medicine. As a peer reviewer you would be asked for your views on the clinical relevance, validity, and accessibility of specific topics within the journal, and their usefulness to the intended audience (international generalists and health care professionals, possibly with limited statistical knowledge). Topics are usually $2000-3000$ words in length and we would ask you to review between 2-5 topics per year. The peer review process takes place throughout the year, and our turnaround time for each review is ideally 10-14 days.

If you are interested in becoming a peer reviewer for Clinical Evidence, please complete the peer review questionnaire at www.clinicalevidence.com or contact Claire Folkes(cfolkes@bmigroup.com). 